\title{
THE EFFECT OF SILAGE PREPARED IN DIFFERENT WAYS UPON THE AMMONIA CONTENT OF THE COW'S RUMEN INGESTA
}

\author{
MARTTI LAMPILA \\ Agricultural Research Centre, Department of Animal Husbandry, \\ Tikkurila, Finland.
}

Received May 21, 1960

The microbial flora of the rumen is able in its cellular synthesis to evaluate ammonium nitrogen for the building of proteins. Attempts have therefore been made in the feeding of ruminans to replace part of the protein requirements of the animals by supplying ammonium nitrogen, or nitrogen compounds decomposable into ammonia, e.g. urea (for review, see e.g. 8). Under certain conditions it seems to be possible to reduce the fodder costs and to make a profit in this manner (10).

In order to replace proteins with ammonia nitrogen (or its equivalent) in the feed of animals, it is necessary for such a feeding to increase the protein synthesis of the microbial flora and for the extra protein to be used to satisfy the protein deficiency and/or the safety margin included in the protein standards.

An effect of the ammonium addition on the synthesis, which is the fundamental prerequisite, is possible when the ammonia quantity derived from other sources such as the various nitrogenous constituents of the fodder and the decomposition of urea in the saliva is inadequate for maintaining the optimum ammonia concentration in the rumen contents for the cellular synthesis of the microbial flora. On the other hand there is the possibility that the feeding leads to an increase in the ammonia concentration to a point detrimental to the microbial flora and to the animal itself. It is therefore necessary to determine the optimum concentration and to study the possibilities of maintaining it on the correct level.

In recent years, ammonium bisulphate (so-called A.I.V. ensilage salt) has been used in Finland in the preparation of silage. A fairly great quantity of ammonium nitrogen from this salt remains in the fodder and it has been maintained that part of this additional nitrogen is utilized by the animal as additional protein (12). The use of this salt is considered one of the practically applicable methods by which ammonium nitrogen can be administered. This fact and the preceding arguments induced the author to study the effect of the feeding of such silage on the ammonia 
concentration of the rumen contents. This paper presents the results of experiments in which three types of silage fodder prepared by other procedures were employed as comparison fodders. The work is part of the research programme on the protein synthesis by the microbial flora in the rumen, which could be carried out with the support of a grant from the Tiura Foundation in 1958.

\section{Experimental procedure}

The experimental animal was an Ayrshire cow with a rumen fistula.' The animal was fed at 12-hour intervals, i.e. at 4.30 and 16.30 hours every day. The daily fodder dose consisted of $5 \mathrm{~kg}$ timothy hay, $1.3 \mathrm{~kg}$ concentrate mixture (Hankkija No. 1, Containing $38.5 \%$ crude protein), $100 \mathrm{~g}$ mineral salt mixture and $18 \mathrm{~kg}$ silage. The silage was made of chopped timothy-clover with a crude protein content of $15.5 \%$ in the dry matter. The ensilage was done by four different procedures: (1) with A.I.V. acid, (2) with A.I.V. ensilage salt, (3) with Calcifor salt, and (4) without any preservative. Detailed information concerning the ensilage procedures, the composition of the resulting fodders and their digestibility has been given

Table 1. The daily dosage of silage, and the composition of the silage fodders.

\begin{tabular}{cccccc}
\hline Silage processed & $\begin{array}{c}\text { Quantity } \\
\text { adminis- } \\
\text { tered } \\
\mathrm{kg}\end{array}$ & $\begin{array}{c}\text { Dry } \\
\text { matter }\end{array}$ & $\begin{array}{c}\text { Dry } \\
\text { matter }\end{array}$ & $\begin{array}{c}\text { Total } \\
\mathrm{N}\end{array}$ & $\mathrm{NH}_{4}-\mathrm{N}^{2}$ \\
\hline With A.I.V. salt & 18 & 19.5 & 3.5 & $\mathrm{~g}$ & $\mathrm{~g}$ \\
A.I.V. acid & 18 & 19.6 & 3.5 & 94.0 & 26.7 \\
Without preservative & 18 & 20.1 & 3.6 & 89.6 & 5.6 \\
\hline
\end{tabular}

elsewhere (9), Table 1 shows data on the composition of the administered silage quantities, derived from analyses of fodder samples taken at the same time as the rumen samples.

Each kind of ensilage was given during not less than seven days before the first series of samples was drawn. The samples were taken from the upper and lower parts of the rumen in a manner that has been descriebed before (5). Three series of samples were taken during each kind of diet, either on successive days or at intervals of one or two days. The results shown are means of these series.

The ammonia was determined by Conway's method (3), using a mstandard unit». $1 \mathrm{ml}$ of the sample suitably diluted to be analyzed was used. The ammonia was liberated by adding $1 \mathrm{ml}$ of saturated $\mathrm{K}_{2} \mathrm{CO}_{3}$ solution. The dishes were kept for three hours at room temperature (about $20^{\circ} \mathrm{C}$ ) and the ammonia bound by the boric acid was then titrated with $0.01 \mathrm{~N}$ sulphuric acid. 
The ammonia concentration curves plotted by the means representing each time of sampling have been shown in Fig. 1. In order to facilitate comparisons between the different diets, Table 2 also contains the average concentrations on each diet, separately for the first and second halves of the feeding period and for the entire period, as well as the relative values of the last-mentioned figures.

As can be seen from Fig. 1, the changes in concentration follow a curve similar in shape to that presented by Butz et al. (2) for the average changes observed in their tests during indoor feeding. They are characterized by the fact that the strong increase after feeding is succeeded by an abrupt decrease, causing the minimum concentration to be achieved about half-way between the feedings or somewhat later.

As has already been said in the description of procedure, samples were taken at the same time from the upper as well as the lower part of the rumen, as it was considered that the means obtained from them gave more accurate idea of the

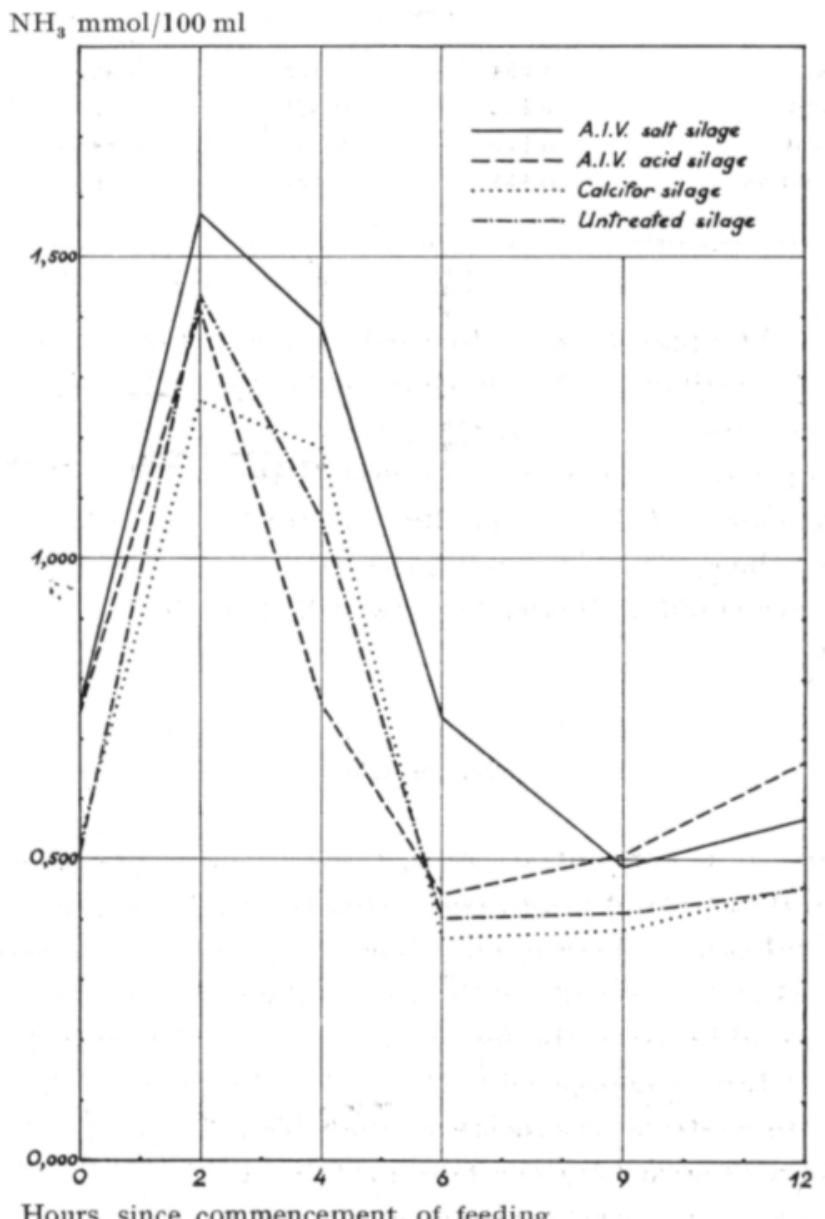

Hours since commencement of feeding.

Fig. 1. Ammonia concentrations of the rumen fluid on different silage diets. 
ammonia content of the rumen ingesta than would have been obtained by taking samples from one point only. It was also desirable to find out whether there are similar regular differences between the different parts of the rumen as occur in the concentrations of volatile fatty acids owing to a stratification of the fodder $(5,6)$. An effect of this kind, though less distinct than in the cited instance, could indeed be noted in the first half of the period between feedings. If one takes into account the first three 2-hour measuring periods of each diet, i.e. altogether 12 periods, the mean concentration in the upper part of the rumen exceeded that in the lower

Table 2. Mean ammonia concentrations of the rumen fluid and their relative values on different silage diets. Contents in $\mathrm{mmol}$ per $100 \mathrm{ml}$.

\begin{tabular}{rcccc}
\hline Silage processed & \multicolumn{3}{c}{$\begin{array}{c}\text { Hours since commencement } \\
\text { of feeding }\end{array}$} & $\begin{array}{c}\text { Relative means } \\
\text { for period bet- } \\
\text { ween feedings }\end{array}$ \\
& $0-6$ & $6-12$ & $0-12$ & \\
\hline With A.I.V. salt & 1.234 & 0.572 & 0.903 & 132 \\
A.I.V. acid & 0.921 & 0.531 & 0.726 & 106 \\
Without preservative & 0.965 & 0.400 & 0.683 & 100 \\
\hline
\end{tabular}

part in 10 cases. The opposite was observed in one instance of Calcifor silage and of untreated silage feeding, both referring to the first 2-hour period. Comparison of the mean concentrations during the first six hours shows that the ammonia content in the upper part of the rumen ingesta exceeded that in the lower part by 20 per cent in the case of A.I.V. silage diet and by 11, 7 and 5 per cent in the tests with A.I.V. salt silage, Calcifor and untreated silage, respectively. This fairly consistent difference could no longer be established in the latter half of the periods between feedings.

\section{Discussion}

The mean ammonia concentrations in the rumen ingesta on administration of A.I.V., Calcifor and untreated silage are so closely equal that the differences cannot be considered significant. There is only one point that is of interest in this comparison, namely, that in the tests with A.I.V. silage the concentration during the first half of the period between the feedings was clearly lower and in the latter half correspondingly higher as compared with results obtained on the other diets.

The changes in material composition that occurred in the A.I.V. salt fodder during preservation (assessed by the true protein, acetic acid and lactic acid contents and the press juice losses) were approximately equal in order of magnitude to the averages of the other three test members. As, moreover, the mean ammonia 
concentrations in the rumen during feeding of the other three types of fodder were closely equal, they can be used as a composite reference group to which the results obtained with A.I.V. salt fodder are compared. The comparison reveals that the ammonia from the preservative salt retained in the fodder has increased the ammonia concentration of the rumen ingesta by $0.177-0.220 \mathrm{mmol}$ per $100 \mathrm{ml}$. The percentage increase which is of significance under the particular test conditions, was $24-32 \%$.

The work in progress concerning the protein synthesis of the rumen microbial flora, has as a preliminary result shown that an increase of the ammonia concentration in the cultures results in its steeper decline in a given concentration range. As the variations in concentration shown in Fig. 1 fall within this range, the inference can be drawn (see e.g. 7,13 ) that the ammonium increment contained in A.I.V. salt fodder has increased the protein synthesis in comparison with conditions on other diets.

However, one cannot conclude from the curves in Fig. 1 that the consumption rate of ammonia would have increased as it has done in the cultures, since the decline after the peak in the concentration curve is no steeper in the case of A.I.V. salt fodder diet than in the other instances. It seems, however, that this can be accounted for by the fact that the ammonia of the silage fodders is absorbed in the vegetable mass and obviously diffuses only slowly into the surrounding fluid in the rumen. The samples drawn from the rumen contents consisted either of free rumen fluid (samples from the lower part) or fluid derived from the fodder mass by comparatively slight squeezing (samples from the upper part). As the ammonia concentration in the A.I.V. salt silage was much higher than that in the other types, and the concentration in the water constituent of this fodder was many times that of the maximum concentration in the rumen fluid, it is likely that the abatement of the concentration curve was delayed by the higher rate and longer duration of diffusion, as compared with the other instances.

VIRTANEN and LAND (12) have employed ${ }^{15} \mathrm{~N}$ to investigate the utilization of ammonium nitrogen given to milk cows for the synthesis of various amino acids; at the same time they drew conclusions from the secretion of ${ }^{15} \mathrm{~N}$, relating to its utilization. They report that about $40 \%$ of the ammonium nitrogen $\left(\mathrm{NH}_{1}\right.$ nitrogen accounted for $10.8 \%$ of the total nitrogen in the administered fodder) was converted to amino acid and protein nitrogen. However, the amount of protein increment apparently obtained cannot be calculated on the basis of this percentage indicating the degree of utilization, because the utilization of ammonia obtained from other sources may be changed by the effect of the administered additional ammonia.

The use of A.I.V. preservative salt for the ensilage of fodder material high in protein has not been recommended (11) on the grounds that the required quantity (e.g. 1.6-1.8 kg per $100 \mathrm{~kg}$ of fresh clover aftermath) has been considered detrimentally high in view of the health of the animals. In the preparation of the fodder used in this work, $1 \mathrm{~kg}$ salt per $100 \mathrm{~kg}$ fresh fodder (dry matter percentage $20.1 \%$ ) was used (9). An estimated $20 \%$ of the ammonia introduced with the salt was expelled with the press juice. Since a daily dosage of $18 \mathrm{~kg}$ did not increase the 
ammonia concentration of the rumen contents any more than has been reported, it appears unlikely that the ammonia content would be the first factor rendering the fodder unhealthy or essentially limiting its administration (cf. e.g. the rumen ammonia concentrations reported 1 and 4). Attention is therefore focused on the sulphate constituent of the salt, indications of its potential harmfulness existing in the form of diarrhoea cases that have occurred during digestibility tests carried out with rams. When relatively higher salt quantities are used in the preserving process or when attempts are made to increase the dosage of this fodder, the further question may arise as to whether the fodder is palatable enough. An elucidation of the effect of these two factors is considered necessary before the possibilities of increased ammonium nitrogen administration in this form can be assessed.

\section{$S u m m$ ary}

The effects on the ammonium content in the cow's rumen ingesta exerted by four types of silage prepared in different ways have been mutually compared. The experimental animal, a fistulated cow, received a daily dose of $5 \mathrm{~kg}$ timothy hay, $1.3 \mathrm{~kg}$ protein concentrates, mineral salt mixture and $18 \mathrm{~kg}$ silage.

The silage had been prepared: (1) with ammonium bisulphate (A.I.V. preservative salt), (2) with A.I.V. acid, (3) with Calcifor salt, and (4) without the addition of preservative.

The mean ammonia concentrations of the rumen contents during the 12-hour period between feedings were, in the above-mentioned order, $0.903,0.726,0.683$ and $0.705 \mathrm{mmol}$ per $100 \mathrm{ml}$, respectively. When the three last-mentioned figures are employed as a basis of reference for the first, the ammonium nitrogen from the ammonium bisulphate retained in the fodder is found to have increased the ammonia concentration of the rumen contents by $0.177-0.220 \mathrm{mmol}$ per $100 \mathrm{ml}$, equivalent to an increase by $24-32 \%$ in the particular conditions of the experiment. The conclusion has been drawn that this has caused increased protein synthesis by the microbial flora of the rumen.

ACKnowledgement: The author wishes to express his respectful gratitude to Tiura's Foundation for a grant that has enabled this work to be done.

REFERENCES :

(1) Briggs, P. K., Hogan, J. P. \& Reid, R. L. 1957. The effect of volatile fatty acids, lactic acid, and ammonia on rumen $\mathrm{pH}$ in sheep. Austral. J. Agric. Res. 8: 674-690.

(2) Butz, H., Meyer, \& H. Körber, KL. 1958. Untersuchungen über den Ammoniakgehalt des Pausensaftes beim Rind. Berl. Münch. tierärztl. Wochenschr. 71: 163-168.

(3) Conway, E. J. 1957. Microdiffusion analysis and volumetric error, p. 98-104. 4th Ed. Glasgow.

(4) Joнns, A. T. 1955. Pasture quality and ruminant digestion. II. Levels of volatile acids and ammonia in the rumen of sheep on a high-production pasture. N.Z.J. Sci. Technol. 37A: 323-331. 
(5) Lampila, M. 1955. Preliminary studies on the variations of $\mathrm{pH}$ and volatile fatty acid concentration of the rumen contents of the cow. J. Sci. Agric. Soc. Finland 27: 142-153.

(6) - $\quad$ \& PoIJ ÄRvi, I. 1959. The formation of volatile fatty acids in the rumen contents of cows in vivo and in vitro. Ibid. $31: 315-320$.

(7) Pearsson, R. M. \& Sмith, J. A. B. 1943. The utilization of urea in the bovine rumen. 3. The synthesis and breakdown of protein in rumen ingesta. Biochem. J. 37: 153-164.

(8) REID, J. T. 1953. Urea as a protein replacement for ruminants: a review. J. Dairy Sci. 36: $955-996$.

(9) RıNG, O. 1959. Säilöntäaineiden käyttö tuoreen rehun säilömisessä. Koetoim. ja käyt.: 6-7.

(10) Schoenfymann, K. \& Kilian, E. F. 1960. Amidfütterung. Stand des Problems, eigene Untersuchungen und Beurteilung der Aussichten. Arch. Tierernährung 10: 37-80.

(11) Virtanen, A. I. \& Aikkinen, I. 1959. AIV-suolarehun laatu. Karjatalous 6-7: 161-162.

(12) - - \& LAND, H. 1959. Synthesis of amino acids and proteins from ammonium salts by ruminants. Acta agral. fenn. 94: 7-13.

(13) Wegner, M. I., Booth, A. N., Bohstedt, G. \& HART, E. B. 1940. The sin vitros conversion of inorganic nitrogen to protein by microorganisms from the cows rumen. J. Dairy Sci. 23: $1123-1129$.

S E L O T U S :

\section{ERI TAVOIN VALMISTETTUJEN SÄILÖREHUJEN SYÖTÖN VAIKUTUS LEHMÄN PÖTSIN- SISÄLLÖN AMMONIAKKIPITOISUUTEEN}

\section{MartTi Lampila}

Maatalouden tutkimuskeskus, kotieläinhoidon tutkimuslaitos, Tikkurila

Selostetussa työssä vertailtiin keskenään neljän eri tavoin valmistetun säilörehun syötön vaikutusta lehmän pötsinsisällön ammoniakkikonsentraatioon. Koe-eläimenä olleen fistelilehmän päivittäinen rehuannos käsitti $5 \mathrm{~kg}$ timoteiheinää, $1.3 \mathrm{~kg}$ valkuaisväkirehua, kivennäissuolaseosta sekă $18 \mathrm{~kg}$ såilörehua.

Sảilörehu oli valmistettu: (1) ammoniumbisulfaattia (AIV-säilöntäsuolaa), (2) AIV-happoa ja (3) Calcifor-suolaa käyttäen sekä (4) ilman säilöntäainetta.

Keskimääräiset pötsinesteen ammoniakkikonsentraatiot 12-tuntisen ruokintavälin aikana olivat samassa järjestyksessä $0.903,0.726,0.683$ ja $0.705 \mathrm{mmol} . / 100 \mathrm{ml}$. Kun kolmea viimeistä arvoa käytetään ensimmäisen vertailukohteina, on ammoniumbisulfaatista rehuun pidättynyt ammoniumtyyppi kohottanut pötsinesteen ammoniakkikonsentraatiota $0.177-0.220 \mathrm{mmol} / 100 \mathrm{ml}$. mikä kokeen olosuhteissa merkitsee $24-32 \%$ :n nousua. On päätelty, että pötsimikrobiston valkuaissynteesi on sen ansiosta lisääntynyt. 